Article

\title{
Agritourism in Mountainous Regions-Insights from an International Perspective
}

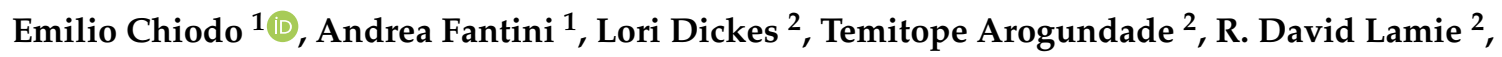 \\ Lucilene Assing ${ }^{3}$, Corinne Stewart ${ }^{4}$ and Rita Salvatore ${ }^{1, *}$ \\ 1 Faculty of Bioscience and Technology for Food, Agriculture and Environment, University of Teramo, \\ Via Balzarini, 1, 64100 Teramo, Italy \\ 2 Department of Agricultural Sciences, Clemson University, 2023 Barre Hall, Clemson, SC 29634, USA \\ 3 Associação de Agroturismo Acolhida na Colônia, Santa Rosa de Lima, Santa Catarina 88763-000, Brazil \\ 4 ISLE Association, 15 Rue des Arts et Métiers, 21000 Dijon, France \\ * Correspondence: rsalvatore@unite.it; Tel.: +39-0861-266908
}

Received: 30 April 2019; Accepted: 1 July 2019; Published: 7 July 2019

check for

\begin{abstract}
Based on the research activity within the ISLE International Sustainability Network, this paper represents a step forward aiming to find some contacts points in the experiences some international cases (USA, Brazil, Italy and France) have grown in the development of agritourism in mountain contexts. Despite the singular differences and the national specificities, agritourism is generally considered a particular form of social innovation in agriculture and rural development of mountainous areas, aiming at recomposing the natural and the human dimensions within the framework of a new sustainable way of doing agriculture. At the basis of the research is the hypothesis that agritourism operations are slowly and gradually shifting towards a new perspective/model. Some years ago, agritourism was traditionally viewed as a way for farmers to integrate or diversify their incomes. Nowadays instead-as the diversity of practice has grown and new values have emerged - the range of farmers' motivations has become much broader. Some of these motivations include not only economic issues but also social, environmental and cultural ones, while addressing a more comprehensive idea of community-based and sustainable development. Case studies from South Carolina (USA), from Italian mountain regions, from Santa Catarina State in Brazil and from France are illustrated in which different innovation perspectives are highlighted.
\end{abstract}

Keywords: agritourism; mountain regions; new peasantries; social innovation

\section{Introduction}

Nowadays there is a wide consensus on the definition of agritourism, which "represents a sustainable on-farm connected, complementary and diversified activity for family conducted working farms with predominating agricultural activities, which are producing for the market to generate additional agricultural income" [1]. The exigence of a shared definition emerges from the success of agritourism, which is in fact a complex and differentiated phenomenon, characterized by multiple forms of relationships between the tourist and the underpinned agricultural activity [2,3], widespread worldwide and affected by the socio-economic characteristics of the different areas in which it developed [4]. Therefore, despite the scientific consensus about its definition, the ways it is practiced and the normative frameworks which regulates it differ from context to context.

Against this complex background, the paper is aimed at investigating the existence of a common file rouge across different international cases and focused on a renewed concept of multifunctionality. The main research objective is then to understand to what extent contemporary forms of agritourism may find a common trait in fostering a particular form of social innovation in agriculture and rural 
development, which points at recomposing the natural and human dimensions within the framework of what Van der Ploeg [5] has defined as the "peasant way of doing agriculture".

At the basis of the research is the hypothesis that agritourism operations, despite the singular differences and the national specificities, are slowly and gradually shifting towards a new model. If the late 1980s represented a way for farmers to integrate their incomes on the basis of hospitality, today it may be considered as a way to develop a new farm management perspective and a new life project, asserting their autonomy from high dependency on external agricultural markets while consciously contributing to the development of rural communities.

Due to the fragility of the physical environments, their socio-economic weakness and their aptitude to match new rural tourists' values and needs, mountain regions represent the specific context in which this phenomenon could be observed. In other words, they might become particular laboratories for socio-economic adaptation [6] through experimentation with new ways to differentiate incomes and to integrate agriculture and tourism. Therefore, the hypothetical idea is that this new approach might empower fragile territorial balances and favor the requalification of areas at risk of abandonment. The farmers would then become actors committed also on a social level, as protagonists of resources enhancement actions and as promoters of social innovation.

Firstly, the paper develops the theoretical framework, analyzing the specificity of mountain regions context, the concepts of social innovation and of new generation agritourism in the light of a sustainable way of doing agriculture. This is followed by a presentation and discussion of some case studies from different regions (USA, Italy, Brazil and France) in which these innovation perspectives are highlighted.

\section{Theoretical Framework}

Since the 1990s, mountain regions have provided a diverse resource base of great interest to new tourism activity [7-9]. Compared to the urbanization that societies have witnessed over more than a century, to the needs of industrial development and to the standardized interactions occurring on a global scale, today, mountain regions and their traditional assets may represent hotspots of both human cultural diversity and unique biodiversity [6]. Many of these regions strongly match new rural tourists' values and needs [10], mainly oriented towards meaningful and highly emotive local experiences [11-13]. The activities related to both ecotourism and "slow tourism" which may take place in these territorial contexts offer a wide range of possibilities for these types of experiences. Whereas eco-tourism is particularly focused on responsible travelling within natural areas [14-16], slow tourism encourages slow mobility (walking, cycling, horse-riding) as a more sustainable means to explore destinations deeply, in search of their regional culture, food and rural traditions [17,18].

Mountain regions have certainly experienced varying degrees of physical barriers to communication and mobility, leading to peripherality, remoteness and massive emigration [19], however, this situation has also generated a strong identification with the natural-cultural landscape for those who remained, as well as for rural tourists. Therefore, mountain regions while providing a rich diversity of fragile landscapes, species, and human values, are also vulnerable contexts and exposed to both internal and external factors impacting individuals' livelihoods and tourists' satisfaction [9]. Fragile physical environments, as well as socio-economic weakness due to marginality, require ongoing innovations to ensure sustainable economic and community development [20]. From this standpoint, we discover many different situations in terms of environmental conservation, tourist attractiveness, and economic prosperity. In some areas we find communities keen in conserving the habitat and the biodiversity they have carved out for themselves (as it is happening in the Indian Himalayan region) [21], in others we are witnessing a complete abandonment (see, for example some cases in the Italian Apennines) [22,23] while in others (like in the European Alps) we register an effort to restore and appropriately reconstruct what has already been lost in terms of both biodiversity and landscape, also due to the development of mass tourism and ski resorts. More generally, thanks to an approach based on social innovation $[24,25]$, local rural communities are now trying to determine new developmental 
paths that open horizons for the sustainable management of local resources in terms of positive benefits to the environment, as well as to agricultural heritage and to rural local economies [26].

As a matter of fact, in mountainous contexts, innovation and sustainable tourism are just two sides of the same coin [20]. If-according to [24] (p. 4)—we consider social innovation "as a motor of change rooted in social collaboration and social learning", then rural communities may represent the social arena where an important change could take place in terms of socio-economical requalification and repopulation. This seems to imply an important "model shift" also in the role of agriculture and in the agritourism offer within local development. It suggests in fact an important qualitative change, in terms of both personal commitment (from the farmers' perspective) and of a more holistic approach to local rural development. Social innovation has to do not only with economic performance but also with natural and sociocultural aspects (which are also considered the focus of tourists' experiences). It implies a multidimensionality which includes also an important immaterial dimension based on the symbolic value of regional products as well as on ideas, services and cultural processes.

Because of all these reasons, mountain areas are now experiencing renewed practices not only from rural tourists but also from "new generation farmers". This group of farmers and business owners seem to take working on a mountain farm, as a "life project", as a challenge toward a better quality of life, than as a purely economic endeavor. There also appear to be both personal and social motivations. Living and working in a mountain region may be linked to personal reasons which also include environmental values and the desire to support the emerging endeavor for sustainable tourism approaches. That is the case for example of Italian new mountains dwellers [27].

Against this background and within the framework of a hypothetical "new generation" agritourism, mountain regions offer the possibility to experiment with a new peasant agriculture [5], which is basically considered in a dichotomic way compared to the agribusiness and entrepreneurial model of intensive agriculture. When talking about new peasantries what we have in mind is rather a "peasant way of farming" [5], related not only to certain activities and practices but also to social relations. If agritourism was traditionally viewed as a way for farmers to integrate or diversify their incomes, as the diversity of practice has grown and new values have emerged, the range of farmers' motivations has become much wider. Some of these motivations include not only economic issues but also social, environmental and cultural ones while addressing a more comprehensive idea of community-based and sustainable development.

The concept of agency in this case is paramount [28]. It focuses on the peasantries' commitment towards territorial/social experiences and alternative ways to address life chances, for them and for their families. In a marginalized context (as mountain regions have often been so far) this peasant way of farming, even if it evokes a traditional way to interact with resources, may represent an innovative means towards autonomy, because it sets farmers' activities in short and often decentralized supply chains which are far from the dependency on neo liberal market dynamics [5]. This shift in agency is innovative as far as may allow for the regeneration and development of self-managed and self-controlled natural cultural resources, as the search and the construction of autonomy is ensured by the relation between the agrarian unit and its mountainous context.

Against this backdrop, the new alternatives that contemporary agritourism has created may allow farmers to react to the constraints imposed by global value chains by using territorial resources to take action and plan "resistance strategies" [29]. These latter include in particular those practices able to reconnect agriculture, nature and society such as a re-association with a "traditional rural world" (increasingly appreciated by new tourists); added value through the development of agrifood processing on farms; the establishment of marketing networks (i.e., nested markets) [30] that also aim at reinforce direct sales to consumers; the development of the hospitality sector and more generally all those diversification strategies that-while offering a diversified portfolio of options-strengthen a territorialized development path embedding both production and consumption into a particular socio-cultural framework. 
This concept of autonomy is precisely related to the axis between farmers and their social context, open to contemporary innovation. Several studies have shown that agritourism, when combined with a vibrant countryside capital [31], can offer an important "tool kit" for revitalizing rural mountainous areas [32-34].

These processes imply forms of "co-production" that while interacting with specific nested markets [30] take into particular account the relation with nature and the reproduction of those resources able to guarantee future perspectives, as well as reducing dependency on wider global markets. Agriculture is then based on a never-ending interaction and reciprocal transformation of man and nature, and in this sense, it represents the process through whom nature is turned into goods and services for human consumption. Thanks to new farming activities and processes, both natural and social relations are constantly modelled, eventually generating new levels of co-production. Coproduction is then centered on the use, the maintenance and the further development of ecological capital. Thanks to co-production mechanisms, farmers can constantly use and more effectively reproduce the resources which give shape to the ecological capital. A productive agrarian process strongly rooted in ecological capital as well as co-production are the main characters of this peasant way of practicing agriculture [5]. At the same time, they strongly underlie agriculture attractiveness in terms of sustainable rural tourism.

Agritourism in mountain regions represents one of the forms this co-production may take. Actually, the interaction between human activities and a vibrant natural countryside is nowadays the premise to culturally differentiate the rural context from the urban one. The interface with nature shapes the tourist encounter in specific forms. Handicraft methods of food production and its quality, the importance of handicraft skills and trades, the predominance of family-run farms, the care for quality, and the management of environmental resources are tightly related elements to the new tourists' sensibility and to their search for "authentic experiences" [35,36].

These changes turn into a qualitative production of both agricultural products and tourist services, and so into an enhanced reproduction. Thanks to a slow improvement of both the quality and productivity of the basic resources (lands, animals, crops, rural settlements, local knowledge etc.) in the long run, farmers may obtain better quality of life through this approach, which is also strongly centered on their sense of autonomy. Thus, the construction and the maintenance of self-managed local resources have strategic importance, and consider sustainable tourism and social development as the two sides of a coin [37]. When managed accurately, resources cannot only be turned into goods and services but also reproduced as renewed resources. This reproduction and expansion of the resource is also meant as the inner mechanism of local heritage creation and re-invention.

The process of agritourism leverages agricultural work, which is firstly the meeting point between man and nature, secondly between farmers and tourists and thirdly the place where the three dimensions articulate reciprocally, often in a creative way. It is a social process because while generating products and services (milk, meat, vegetables, tourist services etc.) it requires a certain combination of natural and human resources, that is a specific style of agricultural management tightly linked to the territorial context. In other words, this orientation of agricultural management has to do with the active creation of products, resources, relations, and symbols, all of which have the potential to yield important positive results for individuals and communities.

\section{Methodology of the Research}

Despite the general consensus on the definition of agritourism, many differences remain within the phenomenon. They concern its features, classification and normative aspects. This may cause some methodological bias, especially in terms of collection of secondary data. The range of agritourism business in fact goes from a very structured organization (like in Italy)-where every single element of the offer (i.e., the maximum number of beds, the family-run, the amount of labor time dedicated to agriculture/agritourism, etc.) is defined by the law-to cases (like in France) where agritourism is not specifically and statistically distinguished among all other tourist activities practiced in a rural 
context [38]. Due to the low level of control over the choice of comparable data collection tools and data collected, the authors opted for the choice of a more flexible research strategy such as multiple-case-study design [39]. This type of method is particularly appropriate when (a) the study focuses on a "contemporary phenomenon to be observed within a context of real life" [39] (p. 33); (b) when exploratory and descriptive purposes need to be satisfied; (c) when the boundaries between the studied phenomenon and the context are not clearly evident [40], (d) when the research can refer to different data sources, depending on the singular situation to observe [41].

This methodology also allows for the observation of the social dynamics related to agritourism. At the same time, it has also enabled an analytic/theoretical possibility to generalize [42]. The comparison has allowed for an examination of heterogeneity across cases and, based on the specificity of the single cases, to come to a general synthesis [40]. If on a first step each case has been analyzed and studied in its specificity, on a second step the comparison among a wider number of cases allows the researcher to get to a broader comprehension of the phenomenon [42]. Therefore, the research has taken into account both the differences among the single cases and their similarities. In this vein, multiple case study research is considered a comprehensive research strategy that has included the development of a theoretical model, data collection and data analysis [43].

Multiple cases of agritourism in the mountainous regions of different countries have been chosen and compared. The choice of the cases has been the product of some of the critical research activities of different units developed within the framework of the ISLE Association (Association for Innovation, of teaching and promoting Sustainable development in Life sciences, applied sciences and social sciences in Europe and in the world) and its participation in the 1st World Agritourism Congress. All four selected countries (Italy, France, USA, Brazil) present important developments of the agritourist phenomenon and significant examples of agritourism as an innovative form to address sustainable agriculture and tourism in mountainous regions. Regional cases have been analyzed in the USA (South Carolina), Brazil (Santa Catarina State) and Italy (Liguria and Marche regions), while for France a case of innovation at national level has been considered. Even if the cases were different from one another they have all been grounded on the same research objectives and questions.

Within this methodological framework, in order to address the impossibility of having a uniform set of data, the research team has used non-standard techniques of investigation, leaving the single research units free to select the most appropriate tools but to integrate lessons learned and conclusions to best represent the advancement of knowledge.

Notwithstanding, a common set of research questions was defined, starting from the literature on the topic and the researchers' experience, such as: the personal, social and economic motivations of agritourism farmers [44,45], their practices and approach to agricultural activities [5], their strategies and operations in agritourism management, their role in rural innovation and territorial development [46] and finally their eventual prior experience in farming activities or other businesses.

These research questions have been used both as a common basis for the elaboration of the questionnaires provided to agritourism farmers both through targeted web-based and direct phone surveys (USA, Italy and Brazil) and as guidelines for personal qualitative in-depth interviews with farmers and other key stakeholders (USA, France). The data collection has concerned also the typology of the facilities available in each agritourism establishment and the personal characteristics of those interviewed such as age, gender, education, professional experience.

Statistical data about the importance of the agritourist phenomenon and its characteristics within the four countries have also been analyzed. The data provided by the surveys are presented in an aggregate manner and privacy issues have been taken into account.

\section{Agritourism in South Carolina Mountain Region: Farmers' Motivating Factors}

The state of South Carolina is in the Southeastern United States and has become a popular destination for tourists, second home buyers, retirees and new residents over the past 25 years. With the state population at over 5 million people and doubling since 1970, South Carolina is among the top 
ten fastest growing states in the United States. South Carolina's growth is unique in that almost $90 \%$ originates from residents moving in from other states [47]. Many of these new residents are settling in the coastal or mountain regions of the state. South Carolina is composed of three distinct geographical regions; the Atlantic coastal plain, the central, Piedmont Plateau region, and the Blue Ridge Mountain region. Seven of South Carolina's 46 counties are in the Blue Ridge Mountain region of the state, with two of the most populous counties in the state in this area. In 2016, Greenville, SC, also in this region, was the 4th fastest growing city in the United States [48].

As the state has grown, there have been converging efforts to develop beginning farmers, coordinate state tourism and agritourism efforts, and to nurture a growing local foods movement. As interest in agritourism has grown in the state, it is imperative to characterize the motivations for the agritourism enterprise. Agritourism has historically been viewed primarily as a way for farmers to integrate or diversify their incomes. However, as the diversity of practice has grown, it appears there are a wide range of motivations for agritourism farmers. Some of these motivations include social, environmental, innovation and entrepreneurial orientation, and to promote community development. A better understanding of the breadth of these motivations is critical for states and regions to clarify, measure and even incentivize these important individual and community efforts. This case study uses several methods to highlight South Carolina mountain region agritourism motivations and areas of focus or interest in the region.

A targeted web-based survey was used to collect data from members of the South Carolina New and Beginning Farmer Program (SC NBFP). This group was chosen because it is a state-wide program that serves individuals who are motivated to be farmers and may be viewing farming and agritourism through a different motivational lens. Approximately $24 \%$ of the agritourism farmers who responded to the survey are beginners (farmers with four years or less of farm operation), while $76 \%$ can be regarded as professional farmers (those with five years or more of farm operation). Approximately half of the agritourism farmers indicate they had prior farming and business experience before starting their agritourism operations. Figure 1 shows the various motivations of agritourism farmers from the sample. As hypothesized, agritourism motivations may be moving away from what are perceived as traditional reasons for engaging in agritourism to choosing this path due to a range of other motivations.

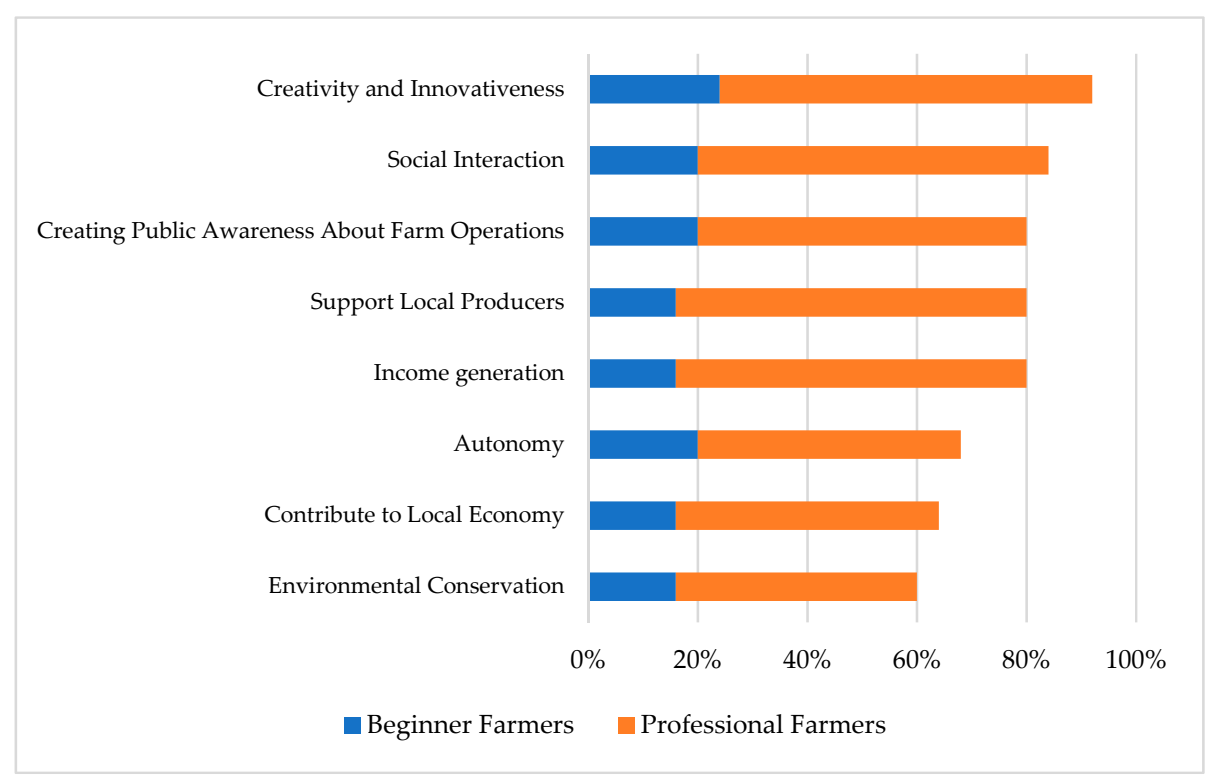

Figure 1. Personal and social motivation of agritourism farmers in South Carolina (\% of respondents). Source: primary data.

From this sample of agritourism farmers, $60 \%$ have ventured into agritourism operations for environmental conservation reasons, while $80 \%$ and $64 \%$ respectively are also in the business to 
support local producers and contribute to the local economy. Approximately $80 \%$ of these farmers invest in agritourism to create public awareness about farm operations, to support local producers, as well as for income generation. Other top motivations for getting into agritourism are creativity and innovativeness $(92 \%)$, social interaction $(84 \%)$, and autonomy $(68 \%)$. The responses illustrate that the rationale for agritourism entrepreneurship goes beyond traditional income diversification. These motivations are not mutually exclusive; it is likely that a farmer has a series of motivations with one that may be the driving reason but others that are also important.

Among these agritourism farmers, $75 \%$ consider their farms to be in very rural or somewhat rural areas. Furthermore, $64 \%$ of agritourism farmers are motivated to contribute to their local economies, which is why rural scholars see agritourism as a tool for rural revitalization and community development. These agritourism farmers have likely contributed to development in their communities, but this research does not estimate the extent of their role in rural innovation and development. However, identified innovative practices of the agritourism farmers in this sample include school tours (46\%), farm animal activities (46\%), educational seminars (41\%), U-pick fruits and vegetables (32\%), farmsteading $(32 \%)$, on-farm processing $(23 \%)$, and wedding venues $(18 \%$ of the agritourism farmers have wedding venues on their farms).

The South Carolina Department of Agriculture (SCDA) reports almost 400 agritourism farm operations in the state. The SCDA classifies agritourism broadly as farm-based activities that supports tourism in agricultural settings. The range of operations considered agritourism is broad and include sales of local products, pick your own operations, seasonal activities (hay rides, apple picking, etc.), and farm to table restaurants. Based on the SCDA database, there are 90 identified agritourism farmers in the seven counties of the mountain region of the state. The operations are largely spread across the four most populous, amenity rich, and developed counties, with the types of agritourism operations being extremely varied.

A scan of the SCDA's agritourism database classifies each operation by whether it has the following characteristics: attractions, accommodations, amenities, direct sales, event space and food service. Only 10 of the mountain region agritourism sites had accommodations on site and only 15 had food service. Respectively, 49 and 48 of the farms had various amenities and event space. Characteristics with the most representation are attractions and direct sales with 69 and 65 agritourism farms respectively. Not every agritourism operator had a complete profile of their operations, however, at least 20 farmers engage in some type of u-pick operation, nine are focused on educational activities and tours, four are involved in museums and festivals, and at least four are involved in positive environmental activities such as tree planting, organic farming, nature preservation, and sustainable agriculture (South Carolina Department of Agriculture, https://agriculture.sc.gov/).

While this brief scan does not reveal substantive detail about each operation, it does illustrate the scope of agritourism operations in the mountain region and highlights operations that signal a range of motivations beyond solely income enhancement. In addition, activities focused on nature preservation and organic farming contribute to the optimal use of the natural environment, favors higher levels of biodiversity, increases food quality and carbon sequestration, and generally minimizes negative environmental impacts [49-52]. Also, activities such as educational operations and tours, community supported agriculture, museums, festivals, and educational research create public awareness, build social capital and identity, develop communities, and contribute to social change [53].

To better understand mountain agritourism farmer motivations, the research team engaged in a formal structured interview with a long-time farmer in the region whose primary purpose was to provide local food direct to the community, as well as being a source of local food security. As a U-pick operation, local and regional tourism contributes to the business, but the focus of the farm is broader than tourist attraction. As the operation has evolved, the farm provides crops for Community Supported Agriculture programs and local farmers markets. However, well over $50 \%$ of the revenue originates from local farm sales. 
The environmental value of the farm is of critical importance to this farmer. They are working on participating in a carbon credit program so that individuals can buy carbon credits from the farm. The farm is also diligent about pest management, soil organic material, planting trees for carbon sequestration and providing education and information on agricultural best practices to the community. Agritourism provides the farmer with a unique opportunity to share his perspectives on the potential role permaculture techniques can play in creating a more sustainable food production system. This farmer believes the farm contributes to community development and tourism as it serves a 27-county radius, along with individuals coming from out of state (and even the country) for vacation in the summer. In conclusion, this farmer's original motivation was largely a seasonal provision of local food and direct farm sales, and this has been successful. However, the motivations have evolved to include a wider range of other motivating force and while the U-pick operation has brought in tourists, tourism is not an intentional consideration of the farmer in comparison to other motivating forces.

In synthesis, South Carolina mountain region agritourism includes a wide range of types of agritourism and a range of amenities and activities on these farms. The statewide survey provides evidence that many new and beginning farmers engage in agritourism activities for motivations beyond income generation. The scan of the SCDA database and structured interview confirm the potential of a wide range of other motivating factors.

\section{Agritourism, New Farmers and Territorial Values. Insights from Italian Mountainous Regions.}

Because of its meaningful growth in recent years, agritourism represents one of the most prominent phenomena of Italian tourism. The number of agritourism farms increased from 6816 (2002) to 18,771 (2017), with a growth rate of $116 \%$. Tourism beds have reached 256,533 , with a growth rate of $149 \%$, doubling their weight on the whole tourist system. Nowadays agritourism represents $9.2 \%$ of the total amount of accommodation establishments and $5.1 \%$ of total beds.

Italian law relates agritourism with agriculture in a tight way. Agritourism activities may consist of: hospitality, catering, farm product tasting, organization of recreational, cultural, didactical, sport and hiking activities. According to the law, in order to be considered an agritourist, these activities must be practiced by farmers (Law n. 96/2006, art. 1) and be always connected to and dependent upon the predominate agricultural activity. For this reason, agritourism has also become a relevant aspect of on-farm diversification. Agritourism farms represent $2 \%$ of Italian farms (2016) and agritourist activities have a value of 1.4 billion euros (2017), 2.7\% of the overall value of Italian agricultural production.

However, this growth has not been uniform everywhere, with some areas having an earlier and more relevant development and others a later and slower one. For example, the Tuscany region and the province of Bolzano alone represent $1 / 3$ of the total number of Italian establishments.

Taking into consideration the most recent trends (years 2012-2017) it is worth noting a higher growth in the number of establishments in regions which had not witnessed the agritourist phenomenon previously: Liguria region $(+20.1 \%)$ and Trento province $(+17.5 \%)$ in Northern Italy, Lazio $(+49 \%)$ and Marche $(+35.8 \%)$ regions in Central Italy, Puglia $(+111.8 \%)$ and Campania $(+66.3 \%)$ regions in the South. In spite of this very relevant growth, the percentage of agritourism farms on the total number of agricultural holdings remains higher in the Central-Northern Italy than in the South.

At a territorial level, agritourism is generally perceived as typical of hilly areas. Hills represent $41.6 \%$ of Italian territory and host the majority of agritourism establishments (52.8\%), connecting agritourism with the popular imagination of the Italian countryside landscape, so well represented by the Tuscan hills.

However, looking at the mountainous areas the broader relevance of the agritourism phenomenon emerges, which risks going unnoticed. In Italian mountain areas, there are 7,353 agritourism establishments, $31.4 \%$ of the total amount. Furthermore, the percentage of agritourism farms is significantly higher in the mountains $(2.4 \%$ of the farms) than in the plains $(0.6 \%)$ or even in the hills $(1.2 \%)$. Also, the growth rate of the number of establishments has been relevant in recent years $(+7.6 \%$ 
from 2012 to 2017). Another important characteristic of agritourism farms is the presence of women as farm managers, about one third of the total.

Within this complex framework, a direct survey was launched with the aim of analyzing the social and entrepreneurial characteristics of the phenomenon and their effects on territorial development of mountain areas. Based on the last five years of growth and on the importance of the mountain areas, two regions have been selected, respectively Liguria region in the North and Marche region in Central Italy. 38 agritourist entrepreneurs (representing $12 \%$ of the total amount working in the two mountain regions of Marche and Liguria) have been interviewed. Their average age is 49 years and they are predominantly women (61\%). They have a medium-high level of study (32\% has a degree, $47 \%$ a high school diploma, $8 \%$ attended a professional course of studies, and only $13 \%$ has no certification at all).

Only two individuals have carried out agrarian studies and eight tourism-focused studies. Most of them have studied in other fields of learning. In most cases, the agritourist profession is completely new: $45 \%$ have never worked as a farmer before; $21 \%$ have worked only as a hobbyist farmer while exercising another profession. Thirty-seven percent of the interviewees started the agritourist enterprise by beginning with a new farm. Therefore, in most cases rather than a way of diversifying, the agritourism establishments represent the start of a new professional career. In fact, $45 \%$ of the entrepreneurs involved in the survey consider themselves beginner farmers.

A different group of interviewees is represented by those who consider their agritourist enterprise as a diversifying tool within an already existing business $(32 \%)$ and by those $(29 \%)$ who consider it as a diversifying activity to begin, after taking over the operation of a family business. In this very last case, agritourism is considered either as an innovative experience within the agricultural profession $(39 \%)$ or within the family tradition $(29 \%)$. Only in very few cases $(13 \%)$ it is considered the "natural" carryover of a family business.

Buy the way, for the majority of operators, the agritourism business represents the main entrepreneurial choice. For $82 \%$ of respondents it is the exclusive or their main business activity. Only for the remaining $18 \%$ it is a supplementary activity.

To better understand respondents' broad orientation, it is useful to examine the analysis of the motivations which stand behind their choice to start a professional experience within agritourism. The most relevant reasons related to "life and professional choice", rather than those associated to purely economic and income objectives. "The choice of a new lifestyle" is the option with the highest score and on average is classified as "very important" (average value $=3.9$ on a maximum value of 5). The importance of different personal and economic goals behind the choice to start a professional experience within agritourism is presented in Figure 2.

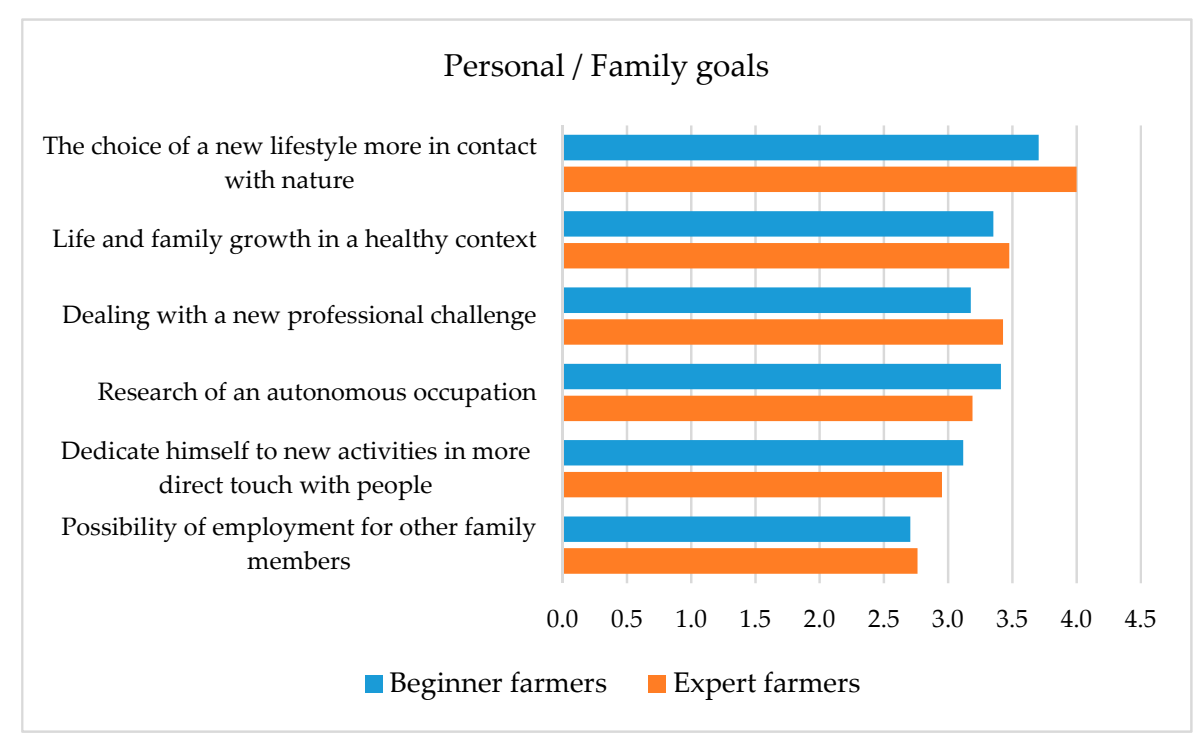

Figure 2. Cont. 


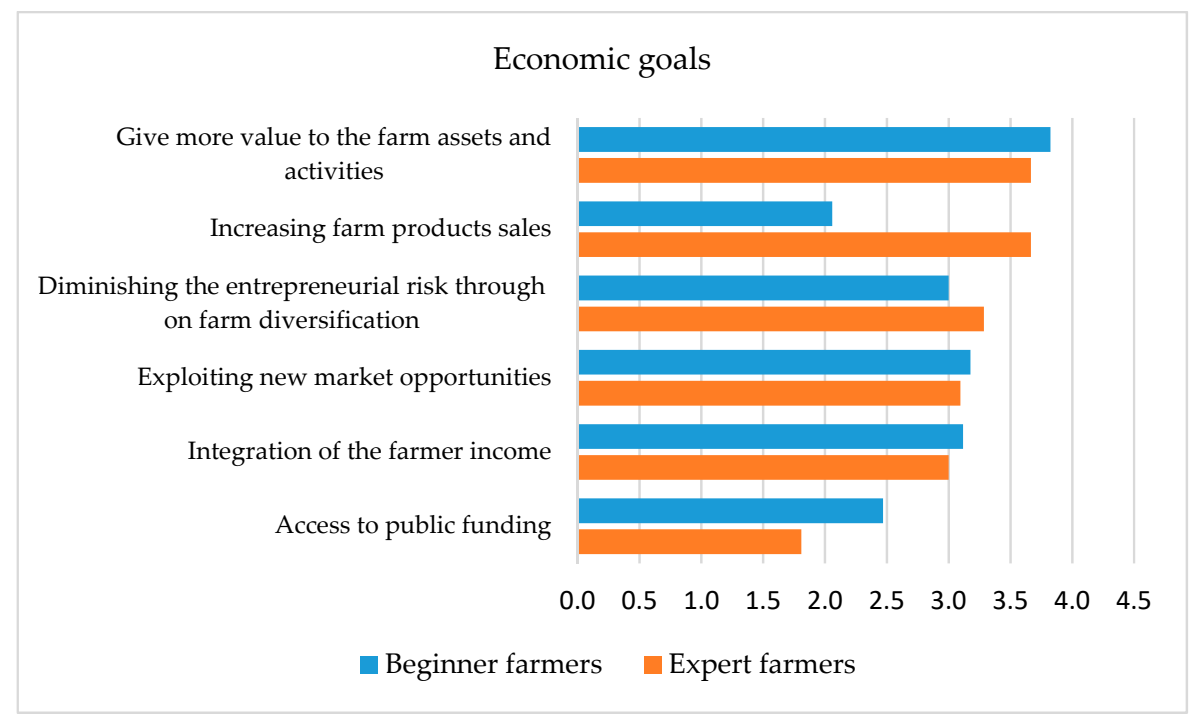

Figure 2. Main motivations to start the agritourism business (1: not important at all-5: extremely important). Source: primary data.

Questioned about the factors related to the success of their activity, agritourism operators rely on aspects such as landscape care (evaluated between important and very important: score 4.5 out of 5), local traditions and culture (4.4), the environmental sustainability of agricultural productions and the use of renewable energies (4.2). On the other hand, as they operate as active players within the territorial development, agritourism operators indicate that their contribution against the abandonment of mountain areas is highly relevant (score 4.4 out of 5) but also their commitment to educating visitors to enjoy the territory and the rural lifestyle (4.4), improving the quality of life in mountain areas (4.3), the landscape care (4.3), the environmental sustainability of agriculture (4.0), and the overall cultural growth of the territory as a whole (4.0).

Finally, respondents' level of satisfaction related to their professional choice, on average is very positive (they are very satisfied: score 4.1). A more specific analysis of the aspects that have improved due to agritourism activity leads to further confirmation of individual motivations. Improvement of quality of life (3.6), of the family (3.5), of social relations (3.6) and the development of the territory (3.5) are valued more highly than the individual's economic situation (score $2.8=$ quite important). These motivating factors highlight the importance of social and cultural values as drivers of agritourism activities.

\section{Young Agritourism farmers' Motivations in Santa Catarina State-Brazil}

"Acolhida na Colônia" (AC) is an association of about 200 farming families, in the State of Santa Catarina, Brazil. The majority of farmers who participate in AC are located in mountain areas. AC emerged in June 1999 to enhance the countryside lifestyle through ecological agritourism, following a movement coordinated by the Association of Ecological Farmers of the Serra Geral (AGRECO), due to the resistance of family farmers who wanted to stay on their land, supported by a group of technicians committed to sustainable development, having as principle the respect for the environment. It is an association of farmers integrated into the Accueil Paysan network, which has been active in France since 1987 [54].

AC represents a dynamic and important phenomenon in the scenario of rural development in the state of Santa Catarina [55]. AC has grown from five regional groups, with 120 families in 2016 to seven regional groups, with 200 families all identifying as farmers (among associates and new farmers being sensitized) in 2018. Currently, out of the AC 200 agritourism establishments, 32.5\% are managed by young farmers and $13 \%$ by young farmers that on average started the agritourism business 8 years 
ago. The range of the number of accommodations is $4-40$ beds, while the average is 12 beds for each agritourism operation.

In 2008, AC won the title of Reference Destination in the Rural Tourism Segment, according to the National Tourism Plan 2007/2010 [56], based on an arrangement made up of four mountain municipalities: Santa Rosa de Lima, Anitápolis, Rancho Queimado and Urubici. In 2018, AC won the National Tourism Award. Such recognitions have brought important benefits, especially to the promotion of tourism destinations in the State of Santa Catarina. AC has been a pioneer in the State of Santa Catarina and can be considered an example of solidarity tourism, as it involves the population from the beginning of the process and offers the opportunity to generate income for young people and adults in the countryside [57]. AC supports principles of agritourism and associativism, which aim to help the farmer stay in the countryside, and contributes to the generation of jobs for young farmers. In the period 2002-2014, the Rural Youth Development Center (Cedejor), which focused on the permanence of young people in rural areas and on the development of agritourism also supported these efforts. The SC Rural Program (2010 to 2016) has been a great supporter of agritourism. It is an initiative of the Government of Santa Catarina with funding from the World Bank and it has the primary objective of increasing the competitiveness of family agricultural organizations by strengthening and structuring their productive chains. For projects connected to AC, the program allocated R\$5.2 million (approximately 1 million $\mathrm{U} \$$ ) in recent years. The resources leverage AC activity with expansions and improvements of facilities, the purchase of equipment and recovery of access roads to the enterprises, among other benefits.

In addition to the benefits to family farmers, the SC Rural Program had programming that helped rural young people gain more advantages than the normal program, but the young farmers of $\mathrm{AC}$ have not been able to form a fairly large group, so they could not access the public incentives. One of the cultural challenges of the geography of the interior of Santa Catarina, is many young farmers have developed agritourism activity on their parents' land. Therefore, as they do not have deed of the land in its name, they do not have autonomy in the development of projects. Further research on generational differences of farmers and the issue of ownership and autonomy is of value for rural communities around the world

\section{Agritourism Young Farmers Survey}

Research was conducted at the beginning of 2019 to determine motivations and behavior of the young generation/new AC farmers. A targeted web-based survey revealed that 22 of the $26 \mathrm{AC}$ agritourism establishments were managed by young farmers. In this sample $46 \%$ are women. Approximately, $45 \%$ of women and $46 \%$ of men are involved in the agritourism operation as the only professional activity, while respectively $58.3 \%$ (female: $72.7 \%$-male: $46.2 \%$ ) and $41.7 \%$ (female: $27.3 \%$-male: $53.8 \%$ ) consider themselves beginners but professionals.

Figure 3 displays AC young farmers' motivations to start an agritourism business. The professional farmers are more likely to be market-oriented, but they are also engaged with environmental aspects and rural lifestyle. The beginner farmers seem to be more concerned about family care in a healthy environment and being in touch with Nature. The interest or the expectations about public funding of the AC young farmers appear to represent the lowest level respondents' motivations. This may, in part be due to the fact that the SC RURAL Program is no longer active and there is not specific public financial support for young farmers to develop agritourism activities.

However, $83.3 \%$ of these young farmers are very satisfied about their choice of life/profession. The perception of the positive ( $1=$ Not at all $-5=$ Very much) effects of their agritourism initiative generally emerges from the sample but is slightly differentiated between women and men. 
Live and grow your family in a healthy environment Self-identity / rural lifestyle Increase sales of farm products

Choice of a new lifestyle more in touch with nature Take advantage of new market opportunities Family connections Possibility of access to public funding

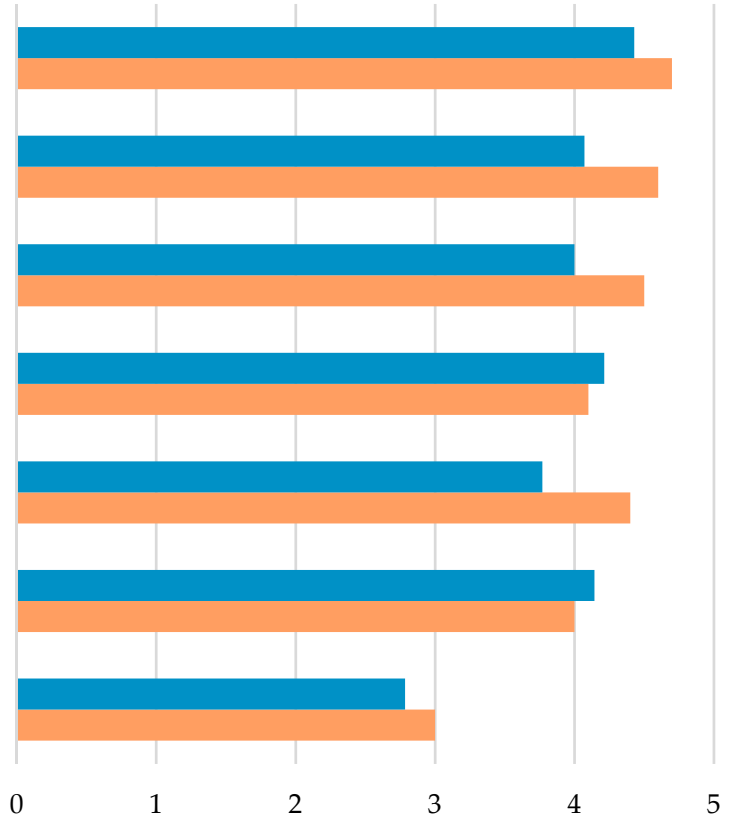

n Beginner farmers $\quad$ Professional farmers

Figure 3. Main motivations to start the agritourism business (1: not important at all—5: extremely important). Source: primary data.

The following responses show the perceived life improvements, both by female and male young farmers, as a result of their agritourism operation:

- Social relations 4.3 (female: 4.18 -male 4.31)

- Development of the territory ... ...... 4.3 (female: 4.09-male 4.46)

- $\quad$ Life quality ................. 4.1 (female: 4.09 -male 4.15)

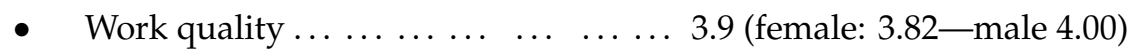

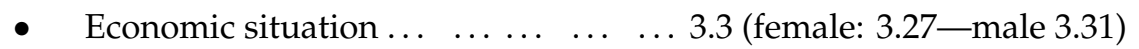

Based on the analysis of these survey outcomes, the female farmer stands out with level of participation, reconciling her functions and roles between the domestic and productive spheres, which without the agritourism activity is already challenging. In fact, in the traditional rural context, women are entrusted with caring for the home, children and the health of the family, as well as the garden and other small farm operations. It is worth noting that in the case studied, besides the traditional roles, women often assume the role of manager of properties and enterprises, bringing another component to their daily lives and generating satisfaction, but at the same time generating difficulties, conflicts and tensions.

Furthermore, various aspects of the benefits and costs of these activities are considered by respondents. The sample population ranks the following possible outcomes as important tools (1: not important at all-5: extremely important) to carry out the agritourism activity:

- Relationship with other farmers in the area $\ldots \ldots \ldots \ldots \ldots \ldots \ldots \ldots \ldots \ldots \ldots$

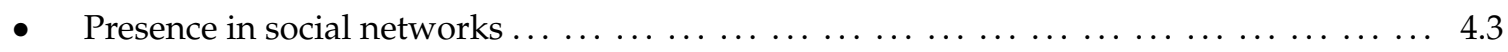

- The relationship with the tourism operators in the area $\ldots \ldots \ldots \ldots \ldots \ldots \ldots \ldots \ldots .0$

- Sale through online tour operators in general $\ldots \ldots \ldots \ldots \ldots \ldots \ldots \ldots \ldots \ldots \ldots \ldots \ldots$

- The sale through specific sites dedicated to the farm $\ldots \ldots \ldots \ldots \ldots \ldots \ldots \ldots \ldots \ldots$ 
An interesting and important output of the survey comes from the question about how much $(1=$ Not at all $-5=$ Very much $)$ various aspects could contribute to the enhancement of the agritourism business:

- Sustainability of agricultural production (low environmental impact, etc.) . . . . . . . 4.6

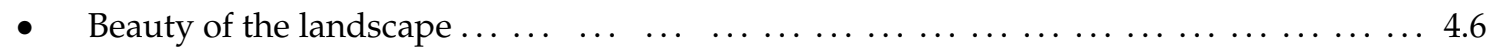

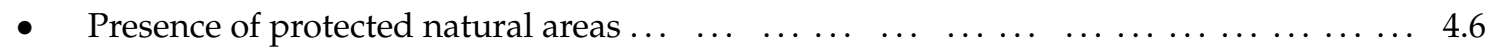

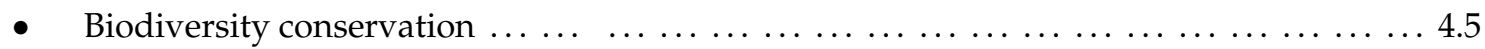

- Adoption of a natural lifestyle $\ldots \ldots \ldots \ldots \ldots \ldots \ldots \ldots \ldots \ldots \ldots \ldots \ldots \ldots \ldots$

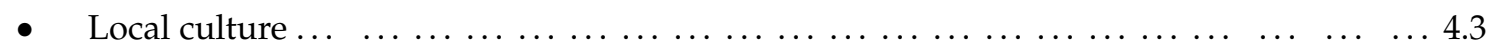

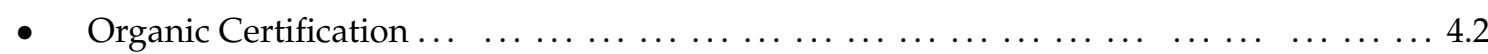

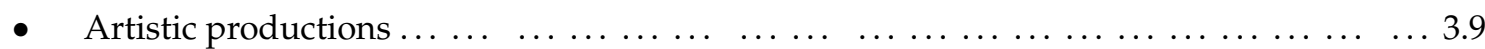

Finally, the survey explores young farmers' perceptions about to what extent $(1=$ Not at all-5 = Very much) different aspects could contribute to the development of the area in which they operate:

- $\quad$ Educate visitors to enjoy the territory $\ldots \ldots \ldots \ldots \ldots \ldots \ldots \ldots \ldots \ldots \ldots \ldots \ldots \ldots \ldots \ldots \ldots \ldots$

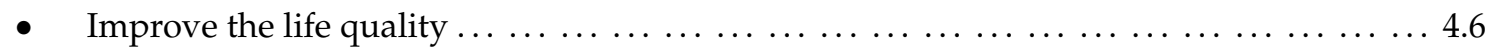

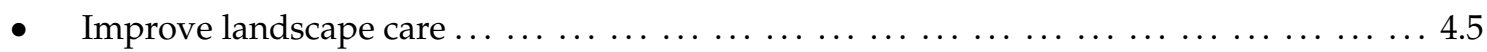

- $\quad$ Making the territory more attractive to young people $\ldots \ldots \ldots \ldots \ldots \ldots \ldots$

The attention of the AC young farmers is likely to be focused on educational activities, on efforts to improve life quality, territorial care, social and professional networks, that seem to converge in a long-term strategy of "total quality" agritourism [58] in which the tourist consumes a mix of tangible and intangible components made up from a variety of services, products and experiences, contributing to territorial development and social innovation in rural areas. The analysis of the case of AC has identified young farmers' motivations and contribution to a sustainable perspective for tourism in a rural geography, especially with regard to the objectives of a better life quality with respect for the environment, which are essential for agritourism in the long term. Survey results reveal that the transformations obtained through agritourism in this population are positive for rural life, especially for the social relations and the quality of life. The AC case represents innovation in agritourism, a collaborative network moving towards a new model to satisfy visitors with the experience of joining the farmer's healthy and natural lifestyle, in an attractive, protected and rich biodiverse environment.

\section{Being Part of a Network: the French Case of "Bienvenue à la ferme"}

With an economic value of 168 billion euros, tourism in France represents $7.25 \%$ of its GDP. Rural tourism plays an important role in the tourist sector, accounting for $21.8 \%$ of tourist activity and $19.8 \%$ of overnight stays of French tourists [59].

Agritourism is a small part of rural tourism and is directly related to stays on farms. It refers to various activities that can be classified into four categories: accommodation (farmhouse inns, camping on the farm, country gites, guesthouses, bed \& breakfasts); catering (table d'hôtes, product-tasting on the farm, farm-to-table restaurants), the sale of services such as educational activities (educational farms, school groups reception and stays) as well as sports and leisure activities (cycling, mountain biking, hiking with or without saddled animals such as donkeys or ponies, horse riding, hunting, fishing, thematic courses). It also includes the direct sale of farm products (fruit and vegetable picking, direct sale of processed products and crafts).

Agritourism accommodation establishments are not classified separately from other rural tourist establishments, but it is possible to affirm that agritourism is a minor form of tourism in the wider context of rural tourism, subjected to the competition of rural but non-agricultural establishments [60]. The various agritourist activities are largely relayed by the "Bienvenue à la ferme" ("Welcome to the farm") label created by the French Chambers of Agriculture or through other organizations managing the classification of 'non-hotel' establishments, such as "Gîtes de France" or "Accueil Paysan". 
Considering the importance of agritourism in relation to the agricultural sector, the last agricultural census in 2010 showed that out of the 490,000 farms in France, 13,800 (2.81\%) had an agritourism activity, $1.94 \%$ were active in offering accommodation, $0.48 \%$ offered some sort of restauration and $0.91 \%$ offered leisure activities. Indeed, agritourism is a relevant part of the diversification strategy of the 56,700 French farms which developed one or more para-agricultural activities to complement their income, which also includes $12 \%$ of all metropolitan farms. Farmers have diversified their agricultural activities either as a primary or secondary function on their farm. The range of production, the potential of their land assets, as well as the diversity of their location opens a wide field of diversified activities on farms such as accommodation, catering, leisure, educational visits, transformation of farm products, crafts, custom-made artisanal work and the production of renewable energy.

The weight of agritourism activities in diversification is progressing overall. These activities are found more frequently in geographical areas offering tourist attractions (coastal and mountain areas), as well as those with a strong heritage identity. Some farm specializations are more easily reconcilable than others with a tourist activity. The availability of the farmer also plays an important role: systems requiring a continuous presence of the farmer can be conducive to the development of agritourism activities. In mountain areas, livestock farms (sheep, goats) have the strongest tourist appeal. In addition, these farms are run by a large proportion of women farmers who are particularly keen to develop such activities.

\section{The Experience of "Bienvenue à la ferme" ("Welcome to the Farm")}

Agritourism is now an annual activity for farmers in France and they have access to specific assistance from the national Chambers of Agriculture which support the rural tourism sector in general. They provide technical advice, specific training, professionalization and provide stakeholder networking.

Forerunners in this domain, they created a brand called "Bienvenue à la ferme" (BAF) in 1988. The BAF network currently associates 8000 member farmers. This initiative sustains French agriculture by offering the opportunity to sell farm products directly to consumers with the "Eat farm products" initiative but also to extend the experience on the farm through "Live on the farm" activities. The first initiative counts for 4400 on-farm selling points, 720 farmers markets, 110 Farm drive-thrus ("Drive Fermier") selling only local farm products and 26 farm shops. The second initiative counts 1800 associated establishments (camp sites, country gites, guesthouses, bed \& breakfasts), 900 farms with recreational, didactical and social activities and 270 farm restaurants [61]. The evolution of the network's functions over time should also be highlighted:

Originally conceived as a network of farmers who were very isolated at the time and less numerous, "Welcome to the farm" has become a brand and a show of quality for the farmers selling their products directly or through short circuits, or via agritourism. This national brand, with its strong reputation ( $48 \%$ of French people know at least the logo), allows these farmers to differentiate themselves in an increasingly competitive market. They also benefit from the visibility on the Bienvenue-a-la-ferme.com website, as well as from the experts support from the network of Chambers of Agriculture which are owners of the brand. It is a network of farmers for farmers and their values have remained firmly anchored: quality of the welcome and products, friendliness, (behind each flower logo "Welcome on the farm" there is a farmer). [ ... ] The majority of the "Welcome to the farm" members now represent the "Eat farmer products ("Mangez Fermier") component with production and transformation on the farm and direct or short-circuit marketing. A large part of the members also offers agritourism activities. (Interview with Jean-Marie Lenfant, Spokesperson of Bienvenue à la ferme)

The key elements for joining the network seem to be the quest for economic viability of the farm in terms of return of investment and also the wide-range of services that BAF offers, such as a common website, communication tools (press releases, social networks, and participation in thematic and professional trade fairs, marketing...). The members' profile has also changed over the years with 
the arrival of people coming from a non-farming background: after a change of career, these people have converted to farming and often offered more unusual products or activities such as saffron and aromatic plants.

Being part of "Welcome to the farm" is a real job that goes beyond agricultural diversification: it means that farmers have to open up to the public, explain their job and share good practices with their colleagues. Even it is difficult to speak of a new "generation of farmers", because we do not have enough numbers to objectively prove it, we can definitely see a rejuvenation of the members: they are often young ( $<40$ years), with innovative projects, often with a little "offset" compared to conventional agricultural activities. They want to try new approaches, are aware of the interest of communicating, of valuing their activity and mastering digital tools. (Interview with Jean-Marie Lenfant)

In 2018 and for the second year running, Airbnb—the worldwide affirmed tourist platform—and MiiMOSA—a French agricultural crowdfunding platform-collaborated with BAF to support agritourism through a joint call for projects.

As $80 \%$ of advertisements on Airbnb are currently located outside Paris, Airbnb is playing an important role in developing the tourism potential of the French countryside. In several highly rural French "departéments", the number of guests on Airbnb increased dramatically between 2016 and 2018: 160\% for Puy-de-Dôme, 200\% for Corrèze. (Interview with Jean-Marie Lenfant)

Launched in 2015, MiiMOSA is the first crowdfunding platform exclusively dedicated to agriculture and food. Over three years, it has supported nearly 1500 projects in France and Belgium via its platform. Ten winning projects were selected by Airbnb and BAF to accelerate their development and notoriety: Airbnb awards a financial support of up to $€ 5000$ per project; BAF accompanies the winners through their local councilors from the Chambers of Agriculture in setting up their project, and grants them a free 1-year membership to the network.

Mountain areas are a privileged field for applications. The following is an insight into some of the 2019 applicant projects in French mountain areas:

- Elodie and Matthieu settled into the Central Pyrenees 10 years ago where they raise 70 goats in organic farming and transform the milk into various products (https://www.miimosa.com/fr/ projects/aidez-nous-a-creer-notre-gite-a-la-ferme/description?l=fr).

- Establishment of a farm inn proposing authentic family cuisine using farm products. The farm called "Les Vergers d'Entrevaux" is located in a low mountain region near the fortified village of Entrevaux in the Var (https://www.miimosa.com/fr/projects/auberge-a-la-ferme-cuisine-de-cheznous-et-convivialite).

- $\quad$ The Ferme à Laines, a wool farm brings together various species (Angora goats, sheep, alpacas and llamas) producing soft fleece which can be transformed into knitting yarns or other items. The farm is nestled in a small valley in the Pyrenean foothills, in a natural and preserved environment (https://www.miimosa.com/fr/projects/un-elevage-aux-poils).

In 2018, more than 150 farmers were able to propose their agritourism project. 37 projects were launched and more than $€ 115,000$ was raised from 900 contributors. The projects have been selected on the basis of the following criteria: projects to diversify agricultural activity; projects promoting accommodation and tourist reception in rural areas; projects having links to the regional "terroir" (heritage, culture, gastronomy...) and projects with a clear and defined budget approach. The projects chosen (Table 1) have resulted in innovations in: accommodation development of unusual accommodation like yurts, teepees, tree houses; innovations regarding the activities (participative activities, animal mediation...); in communication and promotion: digitalization and communication to reach an ultra-connected target audience, crowdfunding, and online booking platforms are all used to develop these projects and promote the activities. Examples from France illustrate the importance and value of organizational support and empowerment for agritourism efforts in areas where they may be less developed around the world. 
Table 1. Winners of the 2018 Call for Proposals "Welcome to the Farm", Miimosa and AirBNB.

\begin{tabular}{|c|c|}
\hline Description of the Project & Localisation \\
\hline Sleep with bees in a hive-shaped cottage! & Ploërdut, Morbihan, Bretagne \\
\hline Treehouse accommodation: "in the footsteps of Abondance" & Bellevaux Haute-Savoie * Auvergne- Rhône-Alpes \\
\hline Support the creation of an educational vineyard & Chusclan, Gard Occitanie \\
\hline $\begin{array}{l}\text { The 5th element: share an unusual moment in nature - horses, } \\
\text { sheep, cows, deer and deer breeding }\end{array}$ & Castelnau- Rivière-Basse Hautes-Pyrénées * Occitanie \\
\hline The conviviality of sleeping in a Kota on a Savoyard farm & Plancherine Savoie * Auvergne Rhône Alpes \\
\hline Cap sur les ceps: cottage and visits at the Domaine de la Luolle & Moroges, Saône-et-Loire, Bourgogne France Comté \\
\hline Discover a vineyard in an unusual and fun way! & $\begin{array}{l}\text { Saint-Aubin-de- Cadelech Dordogne, Nouvelle- } \\
\text { Aquitaine }\end{array}$ \\
\hline Educational welcome in a balsamic vinegar factory & $\begin{array}{l}\text { Saint-Julien-en-Saint-Alban, Ardeche, Auvergne } \\
\text { Rhône Alpes }\end{array}$ \\
\hline The 4 Seasons Garden—a Spirulina greenhouse & Solliès-Pont, Var, Occitanie \\
\hline An organic farm inn & Rodome, Aude, Occitanie \\
\hline Nature stays for children with disabilities & La Sauve, Gironde, Nouvelle Aquitaine \\
\hline
\end{tabular}

\section{Discussion and Conclusions}

This international overview of the regional cases across the mountains of Europe, of the USA, and of Brazil, has allowed the authors to explore the different evolutions of agritourism in different geographies over recent decades. The paper's objective was then to investigate the capability of agritourism to foster a particular form of social innovation in agriculture and rural development, aiming at recomposing the natural and the human dimensions within the framework of a new sustainable way of doing agriculture.

From incomes integration on the basis of hospitality, a new perspective emerges as a way to assert the autonomy of agritourism farmers from high dependency on external agricultural markets, to develop a new life project and at the same time to contribute explicitly to the development of the rural communities.

The case studies appear to confirm that agritourism, through sustainable agriculture and tourism is indeed an innovative support for rural development of mountain regions, even if there is no a unique and clear definition of the phenomenon across the particular cases. The differences in terms of features, classification and normative aspects inevitably cause difficult gaps in conducting comparative research, especially for the collection of statistical data.

Nevertheless, some interesting similarities emerge from the cases. Concerning the South Carolina mountain region, agritourism, both the statewide survey and structured interviews confirm that many new and beginning farmers engage in agritourism activities for motivations beyond income generation. Furthermore, a relationship emerges between the motivating factors and the contribution of agritourism farmers to broader community, educational, and environmental goals. Future research and policy efforts could benefit from understanding how important agritourism and rural development strategies are for new and beginning farmers, along with the specific motivating factors of this next generation of farmers.

Similarly, in the Brazilian Santa Catarina State, young farmers' associated to AC highlight among their motivations a better quality of life and overall respect for the environment. The transformations obtained through agritourism are positive for rural life, especially for social relations and the quality of life on individuals and families. Further research should focus on the cultural aspects and public funding to facilitate the necessary intergenerational succession, not only in the current AC context but also in other less developed areas of the rural environment of Santa Catarina State. 
The Italian situation shows some similar results. The Italian agritourism farmers in the mountainous areas of Liguria and Marche regions, which are mainly women with a medium-high education level, beginners or innovators of the family business, are driven in their choices by the search of a new life style and a healthier context for growing and supporting their family. They are fully connected with their territory and a peasant way of doing agriculture, giving the highest importance to the landscape care, the local traditions and culture, the environmental sustainability of agriculture and considering themselves as active individuals against the mountains abandonment and builders of a better place to live.

Finally, the French experience shows a structured support system to agritourism that, by mixing networking, communication and marketing strategies with more innovative approaches like crowdfunding, pursues the aim of sustaining more innovative ideas, which can be found in the mountain areas and through young farmers with their new fields of application.

Therefore, several common traits emerge from the cases, such as a quantitative growth and a diversification of the experiences in the agritourism phenomenon; a wide range of motivations-far beyond the economic ones-for starting the agritourism activity; a relevant role of the "new farmers", who are both people coming from other professional experiences, and young farmers succeeding in the family business; and care about the reproduction of local resources through the co-production of agricultural products and tourist services.

The focus on a renewed interest toward a "peasant way" of managing agricultural resources has shown a subtle file rouge which runs across new farmers' motivations and approaches to rural business/tourism regardless of their national context.

This seems to lead to a specific meaning of innovation which focuses on the territorial commitment of these economic actors towards the territory they live and work in. Their quality of life and work is tightly related to both the ecological wealth of a whole territory, the sustainable management of the local resources, their families' prosperity and their claim for autonomy from centralized markets. These elements are not solid enough to allow the authors to confirm the initial hypothesis according to which agritourism in mountain regions is moving towards a specific new model, but definitely suggests future research paths based on new indicators which should be tested and explored in different areas.

Author Contributions: Conceptualization, E.C. and R.S.; Data curation, E.C., A.F., L.D., T.A., R.D.L., L.A. and C.S.; Formal analysis, E.C., A.F., L.D., T.A., R.D.L. and R.S.; Investigation, E.C., L.D., T.A., L.A., C.S. and R.S.; Methodology, E.C. and R.S.; Writing-original draft, E.C., A.F., L.D., T.A., R.D.L., L.A., C.S. and R.S.; Writing-review \& editing, R.S.

Funding: This research received no external funding.

Acknowledgments: The authors would like to thank the following contributors for the precious information provided concerning French agritourism: Jean-Marie Lenfant, Spokesperson for Bienvenue à la ferme; Laurine Latrubesse, Le Bureau de Com; Marjorie Esprit, Chargée de Mission Promotion des Produits et Agritourisme, Chambre Régionale D'agriculture, Occitanie.

Conflicts of Interest: The authors declare no conflict of interest.

\section{References}

1. Eurac Research. Outcome Statement 1st World Congress on Agritourism. 2018. Available online: http: //agritourism.eurac.edu (accessed on 7 June 2019).

2. Phillip, S.; Hunter, C.; Blackstock, K. A typology for defining agritourism. Tour. Manag. 2010, 31, 754-758. [CrossRef]

3. Tew, C.; Barbieri, C. The perceived benefits of agritourism: The provider's perspective. Tour. Manag. 2012, 33, 215-224. [CrossRef]

4. Broccardo, L.; Culasso, F.; Truant, E. Unlocking Value Creation Using an Agritourism Business Model. Sustainability 2017, 9, 1618. [CrossRef]

5. Van der Ploeg, J.D. The New Peasantries. In Struggles for Autonomy and Sustainability in an era of Empire and Globalization; Earthscan: London, UK, 2008.

6. Greenwood, G. Why Mountains Matter. IHDP Update 2008, 2, 4-6. 
7. Poon, A. Competitive Strategies for a “New Tourism"'. In Classic Reviews in Tourism; Cooper, C., Ed.; Channel View: Clevedon, UK, 2003; pp. 130-142.

8. Nepal, S.K.; Chipeniuk, R. Mountain Tourism: Toward a Conceptual Framework. Tour. Geogr. 2005, 7, 313-333. [CrossRef]

9. Godde, P.M.; Price, M.F.; Zimmermann, F.M. (Eds.) Tourism and Development in Mountain Regions; Cabi: Oxon, UK, 2000.

10. Lane, B.; Kastenholz, E. Rural tourism: The evolution of practice and research approaches-towards a new generation concept? J. Sustain. Tour. 2015, 23, 1133-1156. [CrossRef]

11. Kastenholz, E.; Carneiro, M.J.; Peixeira Marques, C.; Lima, J. Understanding and managing the rural tourism experience-The case of a historical village in Portugal. Tour. Manag. Perspect. 2012, 4, 207-214. [CrossRef]

12. Jepson, D.; Sharpley, R. More than sense of place? Exploring the emotional dimension of rural tourism experiences. J. Sustain. Tour. 2015, 23, 1157-1178. [CrossRef]

13. Salazar, A. Hospitality trends: Opportunities and challenges. Worldw. Hosp. Tour. Themes 2018, 10, 674-679. [CrossRef]

14. Ceballos-Lascurain, H. (Ed.) Tourism, Eco-Tourism, and Protected Areas: The State of Nature-Based Tourism Around the World and Guidelines for Its Development; Island Press: Washington, DC, USA, 1996.

15. Nepal, S.K. Mountain ecotourism and sustainable development. Mt. Res. Dev. 2002, 22, 104-110. [CrossRef]

16. Dolnicar, S.; Crouch, G.I.; Long, P. Environment-friendly Tourists: What Do We Really Know about Them? J. Sustain. Tour. 2008, 16, 197-210. [CrossRef]

17. Dickinson, J.; Lumsdon, L. Slow Travel and Tourism; Earthscan: London, UK, 2010.

18. Dickinson, J.; Lumsdon, L.; Robbins, D. Slow travel: Issues for tourism and climate change. J. Sustain. Tour. 2011, 19, 281-300. [CrossRef]

19. Salvatore, R.; Chiodo, E.; Fantini, A. Tourism transition in peripheral rural areas: Theories, issues and strategies. Ann. Tour. Res. 2018, 68, 41-51. [CrossRef]

20. Kuščer, K.; Mihalič, T.; Pechlaner, H. Innovation, sustainable tourism and environments in mountain destination development: A comparative analysis of Austria, Slovenia and Switzerland. J. Sustain. Tour. 2017, 25, 489-504. [CrossRef]

21. Ramakrishnan, P.S. Redeveloping Mountain Landscapes as Cultural Cradles of Biodiversity. IHDP Update 2008, 2, 63-69.

22. Teti, V. Il Senso dei Luoghi: Memoria e Storia dei Paesi Abbandonati; Donzelli: Roma, Italy, 2004.

23. Chiodo, E.; Finocchio, R.; Sotte, F. Diversificazione multifunzionale nell'impresa agricola e trasformazioni del paesaggio agrario. Ital. J. Agron. 2009, 3, 41-46. [CrossRef]

24. Bock, B.B. Rural Marginalisation and the Role of Social Innovation; A Turn Towards Nexogenous Development and Rural Reconnection. Sociol. Rural. 2016, 56, 552-573. [CrossRef]

25. Neumeier, S. Social innovation in rural development: Identifying the key factors of success. Geogr. J. 2017, 183, 34-46. [CrossRef]

26. Chiodo, E.; Adriani, H.L.; Navarro, F.P.; Salvatore, R. Collaborative Processes and Collective Impact in Tourist Rural Villages-Insights from a Comparative Analysis between Argentinian and Italian Cases. Sustainability 2019, 11, 432. [CrossRef]

27. Corrado, F.; Dematteis, G.; Di Gioia, A. Nuovi Montanari. Abitare le Alpi nel XXI Secolo; FrancoAngeli: Roma, Italy, 2014.

28. Chaperon, S.; Bramwell, B. Dependency and agency in peripheral tourism development. Ann. Tour. Res. 2013, 40, 132-154. [CrossRef]

29. Schneider, S.; Niederle, P.A. Resistance strategies and diversification of rural livelihoods: The construction of autonomy among Brazilian family farmers. J. Peasant Stud. 2010, 37, 379-405. [CrossRef]

30. Polman, N.; Poppe, K.J.; van der Schans, J.W.; van der Ploeg, J.D. Nested markets with common pool resources in multifunctional agriculture. Riv. Econ. Agrar. 2010, 65, 295-318.

31. Garrod, B.; Wornell, R.; Youell, R. Re-conceptualising rural resources as countryside capital: The case of rural tourism. J. Rural Stud. 2006, 22, 117-128. [CrossRef]

32. Abrudan, I.; Turnock, D.A. Rural development strategy for the Apuseni Mountains, Romania. GeoJournal 1998, 46, 319-336. [CrossRef] 
33. Ciolac, R.; Adamov, T.; Iancu, T.; Popescu, G.; Lile, R.; Rujescu, C.; Marin, D. Agritourism-A sustainable development factor for improving the "health" of rural settlements. Case study Apuseni Mountains area. Sustainability 2019, 11, 1467. [CrossRef]

34. Ciolac, R.; Csosz, I.; Bogdan, N. Brief description of the agritourism potential of Western Mountains area and identification of the main traditional products possible sold through agritourism. Agrobuletin 2012, 12, 148-154.

35. Sims, R. Food, place and authenticity: Local food and the sustainable tourism experience. J. Sustain. Tour. 2009, 17, 321-336. [CrossRef]

36. Sharpley, R.; Jepson, D. Rural Tourism: A Spiritual Experience? Ann. Tour. Res. 2011, 38, 52-71. [CrossRef]

37. Salvatore, R.; Maretti, M. The Link Between Sustainable Tourism and Local Social Development. A Sociological Reassessment. Sociologica 2012, 2, 1-21.

38. Marcotte, P.; Bourdeau, L.; Doyon, M. Agrotourisme, agritourisme et tourisme à la ferme? Une analyse comparative. Téoros Rev. Rechèrche Tour. 2006, 25, 59-67.

39. Yin, R.K. Case Study Research: Design and Methods; Sage: London, UK, 2003.

40. Meyer, C.B. A Case in Case Study Methodology. Field Methods 2001, 13, 329-352. [CrossRef]

41. Stake, R.E. The Art of Case Study Research; Sage: Thousand Oaks, CA, USA, 1995.

42. Marradi, A.; Archenti, N.; Piovani, J.I. Metodología de las Ciencias Sociales; Emecé: Buenos Aires, Argentina, 2007.

43. Barkley, D.L. The Value of Case Study Research on Rural Entrepreneurship: Useful Method? In Proceedings of the Joint ERS-RUPRI Conference, Exploring Rural Entrepreneurship: Imperatives Opportunities Res., Washington, DC, USA, 26-27 October 2006.

44. Barbieri, C.; Mahoney, E. Why is diversification an attractive farm adjustment strategy? Insights from Texas farmers and ranchers. J. Rural Stud. 2009, 25, 58-66. [CrossRef]

45. Arroyo, C.G.; Barbieri, C.; Rich, S.R. Defining agritourism: A comparative study of stakeholders' perceptions in Missouri and North Carolina. Tour. Manag. 2013, 37, 39-47. [CrossRef]

46. Brouder, P. Creative Outposts: Tourism's Place in Rural Innovation. Tour. Plan. Dev. 2012, 9, $383-396$. [CrossRef]

47. Slade, D. People Relocating from Other States Made South Carolina the 9th Fastest Growing in the US. The Charleston Post and Courier. 19 December 2018. Available online: https: //www.postandcourier.com/business/real_estate/people-relocating-from-other-states-made-south-carolinathe-th/article_999fc8e8-03a4-11e9-91e6-4ba1038fa981.html (accessed on 7 May 2019).

48. Slade, D. It's Official: Charleston is Now South Carolina's Largest City: Greenville among Fastest Growing in Nation. The Charleston Post and Courier. 25 May 2017. Available online: https://www.postandcourier.com/news/ it-s-official-charleston-is-now-south-carolina-s-largest/article_c379a210-4087-11e7-a023-9752f7803e50.html (accessed on 7 May 2019).

49. Fisher, A.C.; Krutilla, J.V. Economics of nature preservation. In Handbook of Natural Resource and Energy Economics; Kneese, A.V., Sweeney, J., Eds.; Elsevier: Amsterdam, The Netherlands, 1985; Volume 1, pp. 165-189.

50. Häring, A.; Dabbert, S.; Offermann, F.; Nieberg, H. Benefits of organic farming for society. In Proceedings of the Organic Food and Farming-Towards Partnership and Action in Europe, Copenhagen, Denmark, 10-11 May 2001; The Danish Ministry of Food, Agriculture and Fisheries: Copenhagen, Denmark; pp. 80-88.

51. Fuller, R.J.; Norton, L.R.; Feber, R.E.; Johnson, P.J.; Chamberlain, D.E.; Joys, A.C.; Wolfe, M.S. Benefits of organic farming to biodiversity vary among taxa. Biol. Lett. 2005, 1, 431-434. [CrossRef] [PubMed]

52. Leifeld, J.; Fuhrer, J. Organic farming and soil carbon sequestration: What do we really know about the benefits? AMBIO 2010, 39, 585-599. [CrossRef] [PubMed]

53. Scott, C. Museums and impact. Mus. J. 2003, 46, 293-310. [CrossRef]

54. Guzzatti, T.C. O Agroturismo Como Elemento Dinamizador na Construção de Territórios Rurais: O Caso da Associação de Agroturismo Acolhida na Colônia em Santa Rosa de Lima (SC). Ph.D. Thesis, Universidade Federal de Santa Catarina, Florianópolis, Brazil, 2010.

55. Fantini, A.; Rover, O.J.; Chiodo, E.; Assing, L. Agroturismo e orientação aos circuitos curtos de comercialização de alimentos orgânicos: Estudo do caso "Acolhida na Colônia". Rev. Econ. Sociol. Rural Resr Sober 2018, 56, 517-534. [CrossRef] 
56. Ministério do Turismo (MTUR). Diretrizes Para o Desenvolvimento do Turismo Rural no Brasil, 2007-2010. Available online: www.pronaf.gov.br/turismo/programadeturismorural.pdt (accessed on 18 April 2018).

57. Walkowski, M.; Damo, M.; Loch, C. Projeto Acolhida na Colônia no Estado de Santa Catarina-Sc: Um território de identidade e turismo sob a ótica da linguagem de padres. Tur. Visão Ação 2017, 19, 2. [CrossRef]

58. Fawcett, S.L. Quality in the agritourism product. Prog. Tour. Hosp. Res. 1996, 2, 79-86. [CrossRef]

59. Khiati, A. Mémento du Tourisme. Édition 2018; Direction Générale des Entreprises (DGE): Ivry-sur-Seine, France, 2019.

60. Fabry, N. Agritourisme: Enjeux socio-économiques et impacts touristiques. Juristourisme 2011, 137, $20-22$.

61. Latrubesse, L.; Gouessous, N.; Besco-Jaoui, D. Mangez, vivez, fermier. Dossier de Presse; Bienvenue à la Ferme: Paris, France, 2018.

(C) 2019 by the authors. Licensee MDPI, Basel, Switzerland. This article is an open access article distributed under the terms and conditions of the Creative Commons Attribution (CC BY) license (http://creativecommons.org/licenses/by/4.0/). 